\title{
LIFE SATISFACTION OF EAST EUROPEAN MIGRANTS IN THREE CLUSTERED EUROPEAN DESTINATIONS
}

\author{
Lect. dr. Diana Mariana Popa \\ University Politehnica of Bucharest \\ dianapopa.upb@gmail.com
}

DOI:10.24193/OJMNE.2018.26.12

\begin{abstract}
This paper looks at the declared levels of happiness and life satisfaction of migrants from three East European countries: Bulgaria, Poland and Romania. The Inglehart-Welzel cultural map is used for grouping the main destination countries for East European (EE) migrants into three clusters: the Protestant cluster, the Englishspeaking cluster and the Catholic cluster. The well-being of East European migrants is compared between the three clusters and with that of natives using data from the first 7 waves of the European Social Survey. The article contains the following findings: both as a group and as distinct groups from the three countries of origin, EE migrants are most satisfied with life in the Protestant cluster and the least happy in the Catholic cluster; democratic structures are a key element for the life satisfaction of East European migrants.
\end{abstract}

Keywords: migration, Eastern Europe, well-being, culture, cluster

\section{Introduction}

Even before officially joining the European Union, large numbers of East Europeans migrated to the West in search of better paid jobs. Soon after the events of 1989 there was a large wave of Romanian emigrants to Germany, Austria and Israel, with a considerable ethnic character. Afterwards, joblessness, low wages, political turmoil, poor state of the healthcare system were push factors for many Romanians who looked to the West for better life and working conditions. In 2016, Romanian, Polish, Italian, Portuguese and British citizens were the five biggest groups of EU citizens living in other EU Member States (Fries-Tersch et al., 2016). In 2008, approximately 2,8 million Romanians were working abroad, most of whom in either Spain or Italy (Sandu, 2010) and recently, in the Romanian mass-media it was estimated that the number of Romanians living abroad is around 3.8 million. These millions of emigrants can be grouped in different typologies and based on several variables, different 
profiles of the Romanian migrant have been constructed, depending on origin and destination community; in a recent study, Sandu (2017) showed that the portrait of the Romanian immigrants in Germany and Nordic countries is quite different from the portrait of the immigrants in Spain or Italy. Pour rural communities exhibit large shares of emigration towards Italy and Spain. These communities are also rather poor in educational capital. In opposition, most emigrants towards the German and Nordic countries come from an urban, richer background, and have higher educational capital (Sandu. 2017). Italy, Spain, the United Kingdom are the destinations most investigated by social researches studying the Romanian migration phenomenon (Bleahu, 2005; Anghel, 2008; Serban \& Voicu, 2010; Marcu, 2015; Ban, 2012; Light \& Young, 2009). As large numbers of Romanians have migrated constantly to Italy and Spain, does it mean that they are happier there when compared to other host countries? A large existing diaspora decreases the costs of migration for future immigrants Collier \& Hoeffler (2018) but does the existence of a large immigrant community in established host countries make immigrants feel happy there or will they be happier in countries where the level of happiness in generally higher, even if they do not have many co-nationals around them? Does a small cultural distance between host and destination country influence the happiness of EE migrants?

To explore these questions, the present article makes use of the European Social Survey data regarding East European migrants in different European countries. For the purpose of statistical analysis, Romanian migrants are considered in this article in the context of a larger group of East-European migrants, consisting also of Poles and Bulgarians. Different social indicators are used in a regression model to see which of them is relevant for the life satisfaction of EE migrants. Drawing on suggestions from previous studies (Polgreen \& Simpson, 2011, Arpino \& de Valk, 2017), I wish to find out whether cultural distance between the origin and destination country has a large influence on the levels of happiness and life satisfaction of East European migrants.

\section{Previous research on the happiness of East European migrants}

Scientists have long been measuring and comparing happiness of individuals and groups, even while acknowledging the fact that happiness is subjective, and there is no objective standard for happiness (Veenhoven 1991). Social indicators are often used in 
research as objective factors influencing happiness or rather wellbeing, as distinctions are made between cognitive evaluation of life and affective wellbeing ${ }^{1}$ (Veenhoven, 1991; Arpino \& de Valk, 2017). Research on the happiness of migrants so far has reached contradicting results, depending on the variables and the target migrant groups and destination countries considered in the analysis. Income (Easterlin, 1974), education (Verkuyten, 2016) and a high or low occupational status (Snel et al., 2015; 2011) have been previously studied as influencing factors on the variation of happiness and on return intentions of migrants.

Verkuyten (2016) showed that in some cases there is an integration paradox, meaning that highly educated migrants declare themselves to be less happy then their lower educated counterparts. There are multiple reasons for this paradox: migrants with higher education are more likely to compare themselves with the majority of the population, have more contact with the members of the majority population, develop higher expectations, and have a better understanding of their reduced opportunities (Verkuyten, 2016). Also, "the integration paradox seems most applicable to immigrants who have invested in host country education” (Verkuyten, 2016). An indicator of the fact that this might not be just a perception is found in the study by Andriessen et al. (2015) which shows that individuals with a foreign name are more often invited to an interview if they send their CV to a job opening where the application procedure allows for "blind” evaluation (without a name mentioned on the CV). On the other hand, Snel et al. (2015) explained that the low occupational status migrants are more likely to declare themselves happy because they consider themselves to be successful when compared to their situation in the origin country: "CEE migrants with uncertain jobs and a low occupational status may be less successful according to the standards of the receiving society and the prevailing academic classification schemes, but may be very successful in their own eyes” (Snel et al., 2015, pp. 18-19).

At a macro level, countries in Northern Europe are seen as happy countries, while happiness is quite low in many East European countries, at least in comparison to Western Europe. (Bartram, 2013). Scholars talk about cultures of dissatisfaction or happy and unhappy countries (Polgreen \& Simpson, 2011). Based on data from the World Values Survey (WVS), that measures the level of happiness on a 4 point scale, as a response to the

\footnotetext{
${ }^{1}$ This paper uses the terms well-being, happiness and life satisfaction as synonyms, acknowledging however the different theoretical components of the phenomenon.
} 
question Taking all things together, would you say you are: 'Very happy'/ 'Quite happy'/'Not very happy'/ 'Not at all happy', East European origin countries of migrants are less happy countries - Poland (3.16) and Romania (2.79) than Western or Nordic destination countries such as Sweden (3.34), the Netherlands (3.24) or Germany (3.06). In very unhappy countries, emigration rates are high (Polgreen \& Simpson, 2011), as is the case of Romania. However, other researchers (Ivlevs, 2015) have found a U-shaped relation between life satisfaction and emigration intentions, with the most and the least satisfied being the ones wishing to migrate.

Many studies on the happiness of migrants rely on comparisons between the scores of migrants and natives regarding happiness or life satisfaction. Based on data from the first six rounds of the European Social Survey (ESS) Arpino \& de Valk (2017) found that, compared to natives, people with a migration background show lower levels of life satisfaction and that this difference is greater for first generation migrants. In other studies too (Voicu \& Vasile, 2014), migrants were found to have higher levels of life satisfaction than stayers from their origin countries but lower levels of life satisfaction when compared to natives in their host countries.

As Arpino \& de Valk (2017) suggest, life satisfaction is influenced by cultural values, depends on the congruence between achievements and aspirations and for migrants is influenced by the group with which they compare their aspirations (Arpino \& de Valk, 2017). Happiness of migrants can be influenced both by levels of happiness in the host country and the origin country in complex ways (Bartram, 2013; Polgreen \& Simpson, 2011), depending also on the comparison reference. One can assume that in many cases, migrants compare their former living conditions with the present ones or the present life conditions with those of natives around them. Veenhoven (1991) criticizes and refines the postulate that happiness results from comparison. He distinguishes between affective and cognitive components of happiness and shows that comparison plays a role only for the cognitive element of happiness, namely contentment, which represents the degree to which an individual perceives his aspirations to be met. Therefore, happiness in the sense of life-satisfaction depends only partly on comparison and partly on personal inclination (Veenhoven, 1991).

\section{Methods, data and results}

In appreciating the cultural distance between country of origin and destination country, I use a similar approach to that used by Brunner \& Kuhn (2018), namely the division 
of culture along the dimensions developed by Inglehart. The Inglehart-Welzel (IW) Cultural Map (2015) is a very useful instrument for culture comparison between countries. Here countries are placed on two scales: the survival-self-expression scale and the traditional secular rational scale. Survival values are opposed to values oriented towards self-fulfilment, self-expression and subjective wellbeing, while traditional values represent the important role given to religion and authority, opposed to the secular rational values, promoting equality, tolerance and acceptance of diversity.

Romania and Bulgaria are in the same cluster of Orthodox countries, closer to survival values, while many West and North European countries are strongly oriented towards self-expression values. Bulgaria is closer than Romania to the secular-rational values, while Poland is closer to the middle of both scales and based on its values it is placed in the Latin America group on the IW Cultural Map developed by Inglehart (2015) and valid for the year 2014². According to the IW Cultural Map, European countries are more different on the survival-self-expression scale than on the traditional - secular rational scale.

\subsection{Data selection}

Taking these cultural differences into consideration and keeping the ecological fallacy in mind, I want to see what the happiness chances are for East Europeans in Northern and Western Europe when compared to more traditional destination countries from the South of Europe. I took as reference the cultural divisions of clusters from the latest version of the IW Cultural Map, from 2013, available online. I looked at the main European destination countries for East European migrants, namely: Austria, Belgium, Denmark, Finland, France, Germany, Ireland, Italy, Luxemburg, The Netherlands, Spain, Sweden, Switzerland, Norway and The United Kingdom. These are grouped on the IW Cultural Map into three clusters. Cluster 1 is the Protestant cluster ${ }^{3}$, composed of Germany, The Netherlands, Sweden, Switzerland. Norway, Denmark and Finland. Cluster 2 is the English-speaking cluster

\footnotetext{
${ }^{2}$ This is an important observation, as countries tend to move on the IW Cultural map influenced by the change in values in a given society over time. Countries that are close to the middle of the two scales have sometimes moved from one Cluster to another, depending on the similarity of values.

${ }^{3}$ There are some variations in literature in the composition of these two clusters as some authors divide them between Western and Nordic states. Sandu (2017) analyses Romanian migration in a cluster formed by Nordic countries Sweden, Denmark, the Netherlands plus Switzerland, and puts Germany and Austria together, based on proximity.
} 
Issue no. 26/2018

composed of The United Kingdom and Ireland. Cluster 3 is the Catholic Europe cluster, composed of Austria, Belgium, Luxemburg, France, Spain and Italy.

The analysis is based on data from the aggregated file of the first 7 waves (20022014) of the European Social Survey. I selected the main European migration target countries of East Europeans, mentioned above. I then selected all cases "not born in country" and with country of birth Bulgaria, Poland or Romania. The resulting sample contained 1437 observations from which 73 had both a father and a mother born in the country (62 respondents were living in Germany and 4 in Austria, countries where people with an ethnic German background emigrated (back) shortly after the fall of the iron curtain). As I wanted to look only at first generation East European migrants, I selected the cases with a father and mother not born in the country and, afterwards, 1300 cases resulted. I also looked at the languages mostly spoken at home and if this was neither (one of) the official language(s) of the host country nor of the country of origin, I eliminated those cases. In the end, the resulting sample had 1296 cases, with 76 respondents from Bulgaria, 858 from Poland and 362 from Romania. The Protestant cluster (Cluster 1) contains 543 respondents, the English-speaking cluster (Cluster 2) contains 422 respondents and the Catholic cluster ${ }^{4}$ (Cluster 3 ) contains 331 respondents. In the case of the "natives" 5 comparison category, I used the same file, selecting from the target countries mentioned above the respondents "born in the country" and with a father and mother born in the country. This resulted in a sample of 149554 respondents.

\footnotetext{
${ }^{4}$ A sample size problem was identified in the case of Italy. Italy and Spain are the two largest destination countries for Romanian migrants (Sandu 2010; 2017; Fries-Tersch et al. 2016; OECD data), given the small language distance and chain migration. The number of Romanian migrants in Italy (OECD data available starting with the year 2008) is over 1 million and in Spain is ranges around 6-7 hundred thousand. However, in the first seven waves of the ESS, In Italy there were only 13 Romanian respondents included in the survey, resulting in an underrepresentation of the Romanian migrant community in the most important emigration country. In comparison, there were 117 Romanian respondents registered Spain and 73 in Germany. As Polgreen \& Simpson (2011) suggest, first generation migrants could be underrepresented in ESS waves because only persons who speak the language of the host country are interviewed, resulting in an overrepresentation of highly educated people. Also, if migrants are not officially registered they cannot get selected based on population or household lists, resulting again in underrepresentation (Bălțătescu 2007).

${ }^{5}$ The category "natives" based on these three variables of the ESS has an instrumental purpose. In this article, the further use of "natives" serves only as a comparison instrument, refers to respondents without a first generation registered migrant background and does not imply any qualitative appreciation of the cultural integration or citizenship of a respondent.
} 
Issue no. 26/2018

\subsection{Hypothesis testing and results}

Geographical distance, language distance (Beenstock, et al., 2001) and cultural distance can influence the migration costs (Polgreen \& Simpson, 2011) but larger difference in cultures per se do not constitute an obstacle to migration (Collier \& Hoeffler, 2018). Therefore, this article does not assume that distance per se influences well-being of migrants, or that cultural distance discourages migration to the respective destination countries, but that distance in cultural values does influence the declared levels of well-being of migrants, as a large cultural distance requires more time and effort to bridge and fit in (Collier \& Hoeffler, 2018). In this perspective, of the three clusters in this study, the Protestant cluster is furthest away from the three East European countries according to the IW Cultural Map, and according to the cultural dimensions of Geert Hofstede (2001). The hypothesis is that the further the host countries are on the IW map from the three origin countries, the lower the life satisfaction (H1a) and happiness (H1b) of East Europeans in those countries will be. Therefore, the subjective well-being of East Europeans in the Catholic cluster should be higher than the levels for the English-Speaking cluster and the latter should be higher than the levels of life satisfaction and happiness from the Protestant cluster.

As shown in Table 1, H1a and H1b are both invalidated: East Europeans are more satisfied with life and happier in the Protestant cluster, then in the English-speaking cluster and only third in the Catholic cluster. Statistically significant differences $(p<0.05)$ were found in Post Hoc tests of the ANOVA (Appendix 2) for the two dependent variables between the Protestant and the English-speaking clusters and between the English-speaking and the Catholic clusters. However, the levels of subjective well-being of natives from the three clusters follows the same pattern: natives are most satisfied with life and most happy in the Protestant cluster, then in the English-speaking cluster and lastly in the Catholic cluster. There is a strong correlation $(0.663, \mathrm{p}<0.01)$, between life satisfaction and happiness for East European migrants in the sample, slightly lower than the correlation in the case of natives (0.0701).

Data in Table 1 and Appendix 1 shows that in all three clusters, East European migrants are less satisfied with life and less happy than natives. This has been explained by other authors also as an indicator that cultures of dissatisfaction can travel (Voicu \& Vasile, 2014), as data from the $4^{\text {th }}$ wave of the ESS for the happiness and life satisfaction levels in the three investigated East European countries shows that these are generally lower than in 
Western, Northern or Southern Europe, leading some scholars to characterize East European countries as "unhappy" (Polgreen \& Simpson, 2011). So, migrating to a happier country will make migrants happier than their national counterparts who remain in their origin country (stayers), but will not make them as happy as the natives from the country they are migrating to. Other studies have found however partially contradicting results: according to Bartram (2013), migrants from Poland are significantly less happy than stayers.

Based on the data presented in Appendix 2, the conclusions of some previous studies (Arpino \& de Valk, 2017; Bălţătescu, 2007) that immigrants show lower levels of life satisfaction when compared to natives is not valid for all countries; exceptions for the life satisfaction level are Belgium, Germany and the United Kingdom, and for the happiness level, Germany and Norway ${ }^{6}$. Looking at data from the first two waves (2002/2004) of the ESS, Bălţătescu (2007) found that East European migrants (all those who came from the post-communist countries in Europe, including from Southern Europe or from European Post-Soviet countries) declared lower levels of life satisfaction and happiness than natives. Comparing this conclusion with the findings from the present article, which shows how in some countries East Europeans are happier or more satisfied with life, exhibits that happiness is indeed not temporarily stable Veenhoven (1994).

Table 1. Averages for life satisfaction and happiness levels of natives and East Europeans. How satisfied with life as a whole are you? How happy are you?

\begin{tabular}{llllll}
\hline & Natives & East European migrants & Natives & $\begin{array}{l}\text { East } \\
\text { migrants }\end{array}$ & European \\
\hline Cluster 1 & 7.75 & 7.48 & 7.84 & 7.67 & \\
\hline Cluster 2 & 7.16 & 6.87 & 7.47 & 7.35 & \\
\hline Cluster 3 & 7.02 & 6.63 & 7.39 & 7.20 & \\
\hline Total & 7.43 & 7.06 & 7.64 & 7.45
\end{tabular}

Where are East Europeans the happiest? As a group they are the most satisfied with life and the happiest in the Protestant cluster. Comparing the average scores of the three migrant groups, the group from Poland has averages over 7 for both dimensions of life satisfaction and happiness (7.18 and 7.50) and Romanian migrants are the least satisfied with

\footnotetext{
${ }^{6}$ In the case of Italy there is also a slight positive difference in the declared level of happiness of East Europeans when compared to natives, but based on the statistical observations presented above, this result should be considered with reservations.
} 
life and the least happy (6.18 and 7.31). ${ }^{7}$ The only statistically representative difference between the three East European migrant groups is between Poland and Romania when looking at life satisfaction level (mean difference $0.365 \mathrm{p}<0.05$ ), while the other comparisons in the one-way Anova are not statistically representative. As shown by data in Appendix 2, East European migrants are most satisfied with life (8.09) and most happy (8.26) in Denmark, the country where also natives are the most satisfied (8.49) and most happy (8.35) of investigated countries.

If we look at the group of East Europeans who are less satisfied with life (answers 1 through 6 on the scale) there is a significant difference between the means of respondents in the first cluster (4.78) and the third cluster (4.22), of 0.557 based on Post hoc HSD, Scheffe and LSD tests $(\mathrm{p}<0.05)$. For the satisfied with life group (answers 7 through 10 on the scale) there is a small significant difference between the means of the first cluster (8.27) and second cluster (8.1), of 0.173 based on a Post hoc LSD test ( $<<0.05)$. Unhappy East Europeans in the Catholic cluster are unhappier than unhappy East Europeans from the Protestant cluster.

If cultural distance between origin and destination country does not predict life satisfaction of migrants, what are the variables that do have a representative impact on this dimension? In the remaining of the article such possible factors are tackled in descriptive analyses and afterwards in a linear regression model.

\subsection{Satisfaction with social and economic conditions}

The findings of Bălțătescu (2007) show that despite lower declared levels of life satisfaction of immigrants when compared to natives, the former are more satisfied with the social and economic conditions of their host country that the latter. An explanation given by the author is the fact that immigrants display higher levels of satisfaction regarding many societal domains as a social comparison effect between host and origin countries (Bălțătescu, 2007). Replicating this comparison with data from the seven waves of the ESS (2002-2014), we see that the conclusion is still valid and that East-European migrants have a higher satisfaction regarding the economic, social and political aspects than native respondents. If we look at the comparison between natives and East-European migrants regarding satisfaction with social and economic conditions (Appendix 3) we see that in almost every

\footnotetext{
${ }^{7}$ It would have been interesting to see in which country are Bulgarians, Poles and Romanians the happiest (if a statistical representative average difference would have been identified). However, due to the small number of respondents in each country from these categories, no such analysis is possible using the present ESS data.
} 
case migrants are more satisfied than natives with the state of the economy, the national government, the way democracy works, the state of education and of health services. The largest difference between natives and East-European migrants is registered for the appreciation of the way democracy works in the host country, with an average difference of 0.7 in favour of the East-European migrants. If migrants compare their new surroundings with the ones in their origin country (Bălțătescu 2007), the fact that they are most satisfied with the way democracy works in the old democracies can be an indicator for dissatisfaction with democracy in their origin countries, which is sometimes part of the motivation to emigrate. As Collier \& Hoeffler have also shown, "this gravity model of migration suggests that differences in income and political freedom between host and origin countries are important factors in the migration decision” (2018, p. 86). There is also a slight difference between the averages of the three clusters in the satisfaction with the democracy dimension, with the respondents from the Catholic cluster reporting a lower score, which is statistically significant $(\mathrm{p}<0.05)$ when compared with the Protestant cluster.

Compared with natives, East Europeans are much more satisfied with the state of the economy in the country in the UK $(+1.81)$, Belgium $(+0.8)$, Germany $(+0.84)$ and Norway $(+0.84)$. Compared with natives, East Europeans are much more satisfied with the national government in Belgium $(+1.1)$, the UK $(+1.86)$ and Norway $(+1.35)$. East Europeans in Spain are much more satisfied $(+1.76)$ than natives with the quality of education. Considerable differences between East Europeans and natives are found in many countries regarding the satisfaction with the state of health services ${ }^{8}$ : Austria (+0.76), Germany $(+0.91)$, Spain $(+1.45)$, Ireland (+1.57). Based on average differences, East European migrants in the Protestant cluster are the closest to natives when it comes to evaluating their satisfaction with social and economic aspects. In line with the reference comparison idea, the above-mentioned positive differences regarding satisfaction with social, economic and political aspects can be interpreted as factors that pull East Europeans towards host countries, and that at the same time push them out of their countries of origin.

\footnotetext{
${ }^{8}$ For the item State of health services in country nowadays there is a statistical representative difference between Bulgaria and Poland (mean difference of 1.435, $\mathrm{p}<.05$ ) and between Romania and Poland (mean difference of .921, $\mathrm{p}<.05)$.
} 
Issue no. 26/2018

\subsection{Education and income}

Based on the sample in the present study, of all East European respondents with tertiary education completed, the largest share (47.9\%) is found in the Protestant cluster, followed by the English-speaking cluster (36.4\%). If we look at the shares that respondents with a higher education have in each cluster, the Protestant and the English-speaking clusters have similar shares (38\%) of East Europeans with a higher education. The largest group of respondents with a low education (less than lower secondary and secondary education) is found in the third cluster - 32\%. A one-way ANOVA on the number of years of completed education shows a similar result. The highest average for years of full-time education completed is found in the English-speaking cluster (14.47). In the Post hoc tests there is a positive significant difference of 0.687 between the English speaking and the Protestant cluster $(\mathrm{p}<0.05)$ and of 1.643 between the English speaking and the Catholic cluster $(\mathrm{p}<0.05)$. This data supports the theory that higher educated East Europeans prefer to go to Englishspeaking countries or countries from the Protestant cluster.

Are well educated migrants less happy then their less educated counterparts, as the integration paradox would suggest? If we look at the portrait of the Romanian migrant in the Nordic countries, as described in the study of Sandu (2017), we see a positive relation between declared happiness and the level of education. In the Protestant cluster, East European migrants are the happiest, and have the highest educational capital, when compared to their counterparts from Italy or Spain. The integration paradox would therefore seem to be contradicted based on this data. East Europeans with a tertiary education in the present study sample have a similar level of life satisfaction and happiness to natives with tertiary education (mean and mode are 8 for both groups), average life satisfaction is 7.67 for natives and 7.32 for EE migrants. Average happiness is 7.83 for natives and 7.62 for EE migrants. When looking at the respondents with a low education level (less than lower secondary and secondary education) the differences become greater: natives have an average life satisfaction of 7.26 and East Europeans of 6.58. Natives have an average happiness level of 7.49 and East Europeans of 7.09. A low education level has a greater impact on life satisfaction and happiness than a higher education level. It seems indeed that happy families are alike, while each unhappy family is unhappy in its own way.

On average, East Europeans in the Protestant cluster report higher income levels than their counterparts in the English speaking or Catholic clusters. 63\% from respondents (valid, 
$\mathrm{N}=1027$ ) in the English-speaking cluster, $41.6 \%$ from the Catholic cluster and $34.6 \%$ from the Protestant cluster are in the first two deciles of income. On the higher end of the income scale, 38\% from the Protestant cluster, 15.1\% from the English-speaking cluster and 28.8\% from the Catholic cluster are in the $4^{\text {th }}$ and $5^{\text {th }}$ deciles. Subsequently, respondents from the Protestant cluster also report higher levels of satisfaction with their income (measured as living comfortably on present income/coping on present income, difficult or very difficult on present income). Model 1 of the Regression in Table 2 shows that in the case of EE migrants only a very low income has a (negative) statistical representative impact on life satisfaction. In this case then also, wealth is subject to a law of diminishing returns and the correlation between wealth and happiness is curvilinear (Veenhoven, 1991). Veenhoven (1991) also showed that the Easterlin's paradox is not that straightforward and that the higher the gross national product, the lower the correlation between individual happiness and relative income.

\subsection{Cumulative factors influencing life satisfaction}

In order to see which indicators have a relevant impact on the life satisfaction of East European migrants, I used a linear regression model, where the dependent variable was "life satisfaction” (How satisfied would you say you are?), as life satisfaction mostly correlates to the cognitive evaluation of social indicators used as dependent variables. The dependent variables used in the linear regression model were introduced in steps. In step one, the demographic control variables were introduced (Model 1). Step two included two more dimensions: country of birth of respondent and cluster of countries the respondent was in. Step 3 introduced general trust and satisfaction with democracy. Satisfaction with the legal system, authorities etc. in host countries were also initially taken into consideration but this lead to multicollinearity. Also, the item "satisfaction with the way democracy works in country" theoretically includes aspects regarding the functioning of the legal system.

In all investigated countries, East Europeans are on average more religious than the natives, the difference between the two group averages being of 0.93. and the largest differences being in Belgium (+1.95), Germany (+1.51) and Spain (+1.48). East European migrants generally attend church more than the natives (38.3\% of natives and $22.1 \%$ of East Europeans migrants never attend church). Church attendance is considered by some authors Rodriguez-Pose \& Berlepsch (2014) as an indicator of social capital, as attending religious services also has a socialising aspect. This is why I included frequency of church attendance 
in the regression models with the factors influencing life satisfaction (Table 2). Model 3 of the regression included frequency of church attendance and socially meeting friends while model 4 excluded the frequency for church attendance in check for stability of socially meeting indicators.

Generalised interpersonal trust is another dimension considered by scholars when looking at happiness levels (Rodriguez-Pose \& von Berlepsch, 2014). In the ESS, generalised trust is measured with the items: Most people can be trusted or you can't be too careful; Most of the time people helpful or mostly looking out for themselves; Most people try to take advantage of you, or try to be fair. East European migrants have lower levels of generalized trust that natives. Compared with each other, Bulgarians are more likely than Poles and Romanians to say that most people can be trusted and try to be fair. Of the three groups, Romanians have the lowest levels of generalised trust based on all three variables. East European respondents from the Protestant cluster have the largest average differences when compared to natives in terms of generalised trust on all three scales. They also have significant larger averages then their counterparts from the Catholic cluster. Romania and Bulgaria are strongly oriented towards survival values, while Poland is only slightly over the midpoint on the survival-self-expression axis and as Inglehart explains, survival values place emphasis on economic and physical security and cultures in this group show low levels of trust. Natives in the Protestant cluster are also the most trusting group of the three clusters. It seems, therefore, that the level of generalised trust in the host country has more influence than the one of the country of origin.

Another factor that has been analysed as having an influence on both the decision to migrate and the levels of happiness of migrants is social capital, measured in the ESS as the frequency of socially meeting friends, relatives, colleagues. This variable was also entered into the regression. Three of the entered variables were considered as being measured on a scale: How religious are you; Most people can be trusted or you can't be too careful and How satisfied with the way democracy works in country. All other variables were transformed from previous ordinal or categorical variables into dummies. References for each category of dummy variables are presented at the bottom of the regression output table. Standardized and unstandardized coefficients for variables entered in different models can be seen in Table 2 .

The variables in the first two sets (demographics, religiousness and cluster) explain $13 \%$ of the variation in life satisfaction. As it is generally the case, bad health and being 
single have a negative impact on life satisfaction. The third group of variables (general trust and satisfaction with democracy) brings an additional significant change of 0.067 in the $\mathrm{R}^{2}$. Believing people can be trusted and appreciating the democratic values from the host country have a positive effect on life satisfaction. The fourth group of variables in model 4 (social capital expressed as frequency of socially meeting others and church attendance) brings a change of only 0.013 . in the $R^{2}$. Never socially meeting friends $(B=-1.009)$ or meeting them less than once a month or once a month $(\mathrm{B}=-0.419)$, and several times a month $(\mathrm{B}=-.368)$ all have a negative and statistical significant impact ( $\mathrm{p}<$ between $0.01-0.1$ ) on life satisfaction when compared to meeting once or several times a week. However, socially meeting daily has no statistical significant impact, even if the B (0.038) is positive in this case. The strongest coefficient $(\beta=0.221)$ corresponds to the variable for satisfaction with the way democracy works in the country $(B=0.212)$. Removing church attendance from the fourth group of variables - Model 5 - increases the $\mathrm{R}^{2}$ to $0.207(\mathrm{p}=0.061)$ and very slightly alters the unstandardized and standardized coefficients for the frequency of socially meeting others.

Satisfaction with the democracy in the host country is a key factor for the happiness of East European migrants in Europe. There is a significant correlation $(0.319, \mathrm{p}<0.01)$ between life satisfaction and satisfaction with democracy for all East European migrants in all three clusters.

The regression model was repeated separately for respondents from Poland and Romania. In the case of respondents from Poland, the following coefficients were significant in the fourth model: over $66(\mathrm{~B}=0.726, \mathrm{p}<0.1)$, (bad health $\mathrm{B}=-1.153, \mathrm{p}<0.05)$, widowed $(\mathrm{B}=$ $-2.520 \mathrm{p}<0.01)$, single $(\mathrm{B}=-673, \mathrm{p}<0.05)$, how religious $(\mathrm{B}=0.094, \mathrm{p}<0.05)$ most people can be trusted or you can't be too careful $(B=0.75, p<0.1)$, Cluster $3(B=-518, p<0.1)$, How often attend church - never $(B=0.643, p<0.1)$, socially meet friends - less than once or once a month $(B=-420, p<0.1)$. For respondents from Romania, the following coefficients were significant in the fourth model: female $(B=0.569, \mathrm{p}<0.1)$, very good health $(B=1.662$, $\mathrm{p}<0.05)$, arrived in the host country within last year $(\mathrm{B}=-2.257, \mathrm{p}<0.05)$, most people can be trusted or $(\mathrm{B}=0.129, \mathrm{p}<0.1)$, how satisfied with democracy $(\mathrm{B}=0.175, \mathrm{p}<0.05)$, socially meeting friends - never $(\mathrm{B}=-1.962, \mathrm{p}<0.1)$. 
Issue no. 26/2018

Table 2: Factors influencing life satisfaction of East European migrants. Regression analysis

15_20years ${ }^{\mathrm{a}}$

21_34years

Over 66

Female

Income 1st quintile

Income 2nd quintile

Income 4th quintile

Income 5th quintile

Less than lower education

Lower secondary education

completed

Tertiary education completed

Very good health

Good health

Bad health

Very bad health

Couple

Separated

\begin{tabular}{|c|c|c|c|c|c|c|c|c|c|c|c|c|c|c|}
\hline \multicolumn{3}{|c|}{ Model 1} & \multicolumn{3}{|c|}{ Model 2} & \multicolumn{3}{|c|}{ Model 3} & \multicolumn{3}{|c|}{ Model 4} & \multicolumn{3}{|c|}{ Model 5} \\
\hline & & Std. & & & Std. & & & Std. & & & Std. & B & Beta & Std. \\
\hline B & Beta & Er. & B & Beta & Er. & B & Beta & Er. & B & Beta & Er. & & & Er. \\
\hline $.937 * *$ & .094 & .425 & $.839 * *$ & .084 & .425 & $.826 * *$ & .083 & .408 & $.715^{*}$ & .072 & .413 & $.726 *$ & .073 & .411 \\
\hline .300 & .072 & .198 & .269 & .064 & .198 & .280 & .067 & .190 & .193 & .046 & .193 & .201 & .048 & .191 \\
\hline $.632 *$ & .079 & .349 & $.617^{*}$ & .077 & .348 & $.577 *$ & .072 & .334 & $.644^{*}$ & .081 & .336 & $.626^{*}$ & .078 & .333 \\
\hline .053 & .013 & .157 & .057 & .014 & .157 & .113 & .027 & .151 & .133 & .032 & .152 & .137 & .033 & .151 \\
\hline$-.543 * *$ & -.103 & .235 & $-.489 * *$ & -.093 & .237 & $-.408 *$ & -.078 & .228 & -.369 & -.070 & .229 & -.369 & $\begin{array}{c}- \\
070\end{array}$ & .228 \\
\hline-.116 & -.024 & .215 & -.110 & -.023 & .215 & -.079 & -.016 & .206 & -.088 & -.019 & .206 & -.082 & $\begin{array}{c}- \\
.017\end{array}$ & .206 \\
\hline .219 & .039 & .244 & .206 & .037 & .244 & .216 & .039 & .234 & .238 & .042 & .234 & .237 & .042 & .233 \\
\hline .418 & .066 & .275 & .332 & .052 & .276 & .251 & .039 & .265 & .290 & .045 & .266 & .295 & .046 & .265 \\
\hline-.431 & -.051 & .328 & -.261 & -.031 & .332 & -.270 & -.032 & .319 & -.316 & -.038 & .320 & -.305 & $\begin{array}{c}- \\
.036\end{array}$ & .318 \\
\hline-.368 & -.066 & .229 & -.296 & -.053 & .229 & -.243 & -.044 & .220 & -.231 & -.042 & .220 & -.247 & $\begin{array}{c}- \\
.044\end{array}$ & .219 \\
\hline .097 & .022 & .181 & .095 & .022 & .183 & -.020 & -.004 & .177 & -.008 & -.002 & .178 & -.003 & $\begin{array}{c}- \\
.001\end{array}$ & .177 \\
\hline $1.213^{* * *}$ & .273 & .250 & $1.258 * * *$ & .283 & .253 & $.915^{* * *}$ & .206 & .247 & $.856^{* * *}$ & .192 & .249 & $.841^{* * *}$ & .189 & .247 \\
\hline $.731^{* * *}$ & .175 & .230 & $.743 * * *$ & .178 & .229 & $.558^{* * *}$ & .133 & .221 & $.530 * *$ & .127 & .222 & $.517 * *$ & .124 & .221 \\
\hline$-.868 * *$ & -.088 & .403 & $-.918 * *$ & -.093 & .402 & $-.793 * *$ & -.081 & .386 & $-.832 * *$ & -.085 & .388 & $-.825 * *$ & $\begin{array}{c}- \\
.084\end{array}$ & .385 \\
\hline$-2.453^{*}$ & -.073 & 1.255 & $-2.369 *$ & -.071 & 1.251 & $-1.965 *$ & -.059 & 1.201 & -1.872 & -.056 & 1.204 & -1.818 & $\begin{array}{c}- \\
.054\end{array}$ & 1.199 \\
\hline-.519 & -.035 & .563 & -.491 & -.033 & .561 & -.202 & -.014 & .539 & -.251 & -.017 & .542 & -.251 & $\begin{array}{c}- \\
.017\end{array}$ & .539 \\
\hline-.679 & -.036 & .703 & -.764 & -.041 & .701 & -.630 & -.034 & .673 & -.518 & -.028 & .676 & -.525 & $\begin{array}{c}- \\
.028\end{array}$ & .673 \\
\hline-.265 & -.034 & .302 & -.343 & -.044 & .302 & -.388 & -.049 & .290 & -.444 & -.056 & .291 & -.427 & - & 289 \\
\hline
\end{tabular}

Divorced 


\begin{tabular}{|c|c|c|c|c|c|c|c|c|c|c|c|c|c|c|c|}
\hline Widowed & $-2.184 * * *$ & -.127 & .675 & $-2.085^{* * *}$ & -.121 & .673 & $-1.942 * * *$ & -.113 & .646 & $-2.084 * * *$ & -.121 & .649 & $\begin{array}{c}- \\
2.060^{* *}\end{array}$ & $\begin{array}{c}- \\
.120\end{array}$ & .646 \\
\hline Single & $-.546 * * *$ & -.125 & .203 & $-.520 * * *$ & -.119 & .202 & $-.449 * *$ & -.103 & .194 & $-.495 * * *$ & -.113 & .197 & $-.482^{* *}$ & $\begin{array}{c}- \\
.110\end{array}$ & .195 \\
\hline Suburb & -.292 & -.051 & .249 & -.321 & -.056 & .253 & -.234 & -.041 & .243 & -.212 & -.037 & .243 & -.219 & $\begin{array}{c}- \\
.038\end{array}$ & .243 \\
\hline Town & .071 & .017 & .201 & .028 & .006 & .205 & .117 & .027 & .197 & .121 & .028 & .198 & .119 & .028 & .197 \\
\hline Village & .058 & .011 & .241 & .064 & .012 & .240 & .094 & .017 & .231 & .091 & .017 & .232 & .101 & .019 & .231 \\
\hline Countryside & .722 & .060 & .468 & .553 & .046 & .471 & .485 & .040 & .452 & .499 & .041 & .452 & .506 & .042 & .450 \\
\hline Within last year & -.640 & -.061 & .435 & -.448 & -.043 & .447 & -.569 & -.054 & .429 & -.563 & -.054 & .430 & -.570 & $\begin{array}{c}- \\
.054\end{array}$ & .428 \\
\hline Between 1 and 5 years ago & -.109 & -.024 & .241 & -.003 & -.001 & .247 & -.188 & -.042 & .238 & -.164 & -.036 & .239 & -.150 & $\begin{array}{c}- \\
.033\end{array}$ & .238 \\
\hline Between 6 and 10 years ago & -.104 & -.021 & .245 & .042 & .009 & .252 & -.107 & -.022 & .243 & -.097 & -.020 & .243 & -.095 & $\begin{array}{c}- \\
.019\end{array}$ & .242 \\
\hline More than 20 years ago & $.596 * *$ & .121 & .259 & $.463 *$ & .094 & .262 & .382 & .077 & .251 & .347 & .070 & .252 & .362 & .073 & .251 \\
\hline How religious are you & .028 & .039 & .028 & .032 & .044 & .028 & .033 & .046 & .027 & .050 & .068 & .032 & .032 & .044 & .027 \\
\hline Cluster 2 & & & & $-.525^{* *}$ & -.118 & .230 & $-.378^{*}$ & -.085 & .222 & -.310 & -.070 & .224 & -.345 & $\begin{array}{c}- \\
.078\end{array}$ & .222 \\
\hline Cluster 3 & & & & $-.580 * * *$ & -.122 & .219 & $-.450 * *$ & -.094 & .211 & $-.477^{* *}$ & -.100 & .212 & $-.479 * *$ & $\begin{array}{c}- \\
.100\end{array}$ & .211 \\
\hline Bulgarians & & & & -.192 & -.022 & .339 & -.387 & -.044 & .326 & -.426 & -.048 & .327 & -.402 & $\begin{array}{c}- \\
.045\end{array}$ & .325 \\
\hline Romanians & & & & -.128 & -.028 & .199 & -.174 & -.038 & .191 & -.201 & -.043 & .192 & -.172 & $\begin{array}{c}- \\
.037\end{array}$ & .191 \\
\hline $\begin{array}{l}\text { Most people can be trusted or you } \\
\text { can't be too careful }\end{array}$ & & & & & & & $.100^{* * *}$ & .109 & .034 & $.095^{* * *}$ & .104 & .034 & $.094^{* * *}$ & .103 & .034 \\
\hline $\begin{array}{l}\text { How satisfied with the way } \\
\text { democracy works in country }\end{array}$ & & & & & & & $.219 * * *$ & .227 & .037 & $.212 * * *$ & .221 & .037 & $.211^{* * *}$ & .220 & .037 \\
\hline Church several times a week or daily & & & & & & & & & & .205 & .018 & .444 & & & \\
\hline Church at least once a month & & & & & & & & & & .018 & .012 & .068 & & & \\
\hline
\end{tabular}


Issue no. 26/2018

\section{Church less often}

Church -Never

Meet socially -Never

B

Meet socially- Less than once a

month or once a month

Meet socially - Several times a

month

Meet socially - Daily

(Constant)

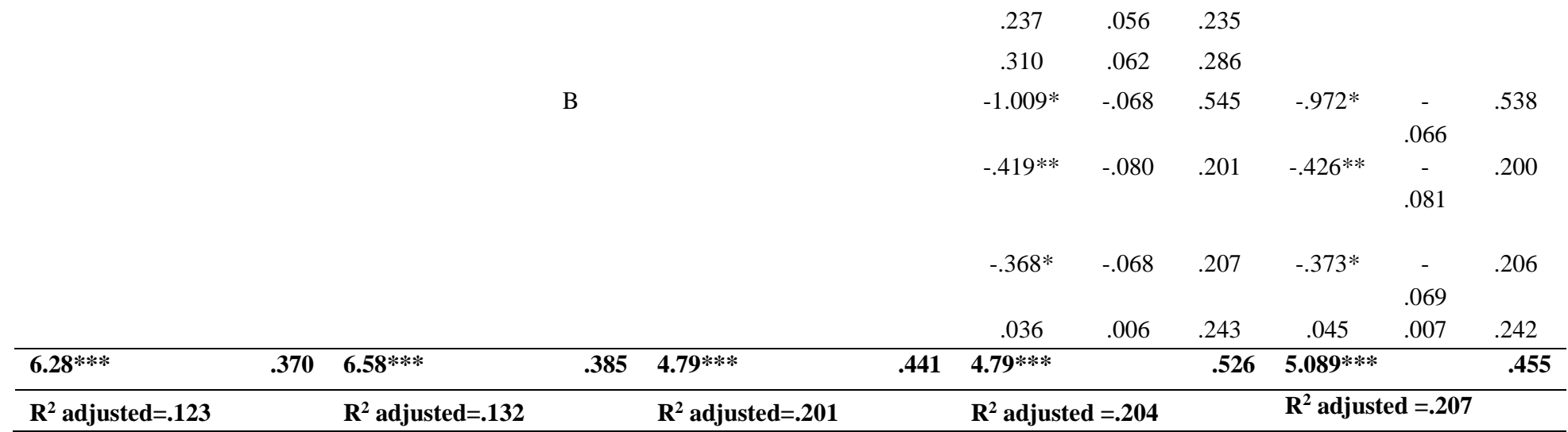

Dependent variable: How satisfied with life as a whole. $(\mathrm{N}=1288)$. Method: Enter. Missing- pairwise

${ }^{* * *} \mathrm{p}<0.01 ;{ }^{* *} \mathrm{p}<0.05 ;{ }^{*} \mathrm{p}<0.1$

Reference categories: Age: 35-49 years; Gender: male; Income: Income 3rd quintile; Education: Upper secondary or post-secondary education completed; Health: Fair health; Marital status:

Married; Residence: Big City; Came in host country how long ago: Between 11 and 20 years ago; Cluster: cluster 1; Country of birth: Poles; Church attendance ref: once a week; How often socially meet friends. Relatives or work colleagues: once a week or several times a week. a=excluded variable: 50_6 
Issue no. 26/2018

\section{Conclusions}

This article provided a comparative view of the well-being of East European migrants in three clusters of target migration countries from Europe. East European migrants represent a large share of the total migrating European population and research about this group based on a comparative approach is still underdeveloped. The main findings of the present article are summarised in the following.

East European migrants are most happy in the countries from the Protestant cluster (Germany, The Netherlands, Sweden, Switzerland, Norway, Denmark and Finland) and in the UK. Unhappy East European migrants in the Catholic cluster are unhappier than unhappy East Europeans from the Protestant cluster.

Countries that are wealthy, well developed democracies, tolerant and well-governed tend to have happier citizens (Polgreen \& Simpson, 2011). Based on the analysis in this study, the level of happiness and of life satisfaction of the host country has a greater influence on the life satisfaction of migrants than the cultural distance between origin and host country. Social and economic conditions matter more than cultural differences for the life satisfaction of East European migrants in Europe. Contrary to expectations, East European migrants are not most satisfied with life or most happy in countries with a small cultural distance to their own. Rather than cultural distance, satisfaction with democracy in the destination country has a greater importance.

As other studies have also shown, (Sandu, 2017; 2010) higher educated East Europeans prefer to go to the countries from the Protestant cluster and to the Englishspeaking countries. A low education level has a greater impact on life satisfaction and happiness than a higher education level. East European migrants are more satisfied than natives with the state of the economy in the UK, Belgium, Germany, and Norway, with the national government in Belgium, the UK, Norway, with the quality of education in Spain, and with the state of health services in Austria, Germany, Spain, and Ireland.

There are also differences between East European migrants regarding which factors have a greater influence on their subjective well-being. Based on the average for all three clusters, migrants from Poland are the most satisfied with life and Romanians are the least satisfied with life and the least happy. For respondents from Poland, religiousness has a 
Issue no. 26/2018

significant positive impact on life satisfaction. For Romanians the start of their life abroad seems to be a difficult time, as having arrived in the host country within last year decreases considerably their satisfaction with life.

\section{Bibliography}

- $\quad$ ANGHEL, G. R. (2008). Changing Statuses: Freedom of Movement, Locality and Transnationality of Irregular Romanian Migrants in Milan. Journal of Ethnic and Migration Studies. Volume 34, 2008 - Issue 5 pp. 787-802. https://doi.org/10.1080/13691830802106069 - $\quad$ ANDRIESSEN, I., VAN DER ENT, B., VAN DER LINDEN, M., DEKKER, G. (2015). Op afkomst afgewezen. Onderzoek naar discriminatie op de Haagse arbeidsmarkt. Sociaal en Cultureel Planbureau. Den Haag.

- $\quad$ ARPINO, B. \& DE VALK, H. (2017). Comparing Life Satisfaction of Immigrants and Natives Across Europe: The Role of Social Contact. Social Indicators Research. Springer.

- BĂLȚĂTESCU, S. (2007). Central and Eastern Europeans Migrants' Subjective Quality of Life. A Comparative Study. Journal of Identity and Migration Studies. Volume 1, number 2 .

- BAN, C. (2012). Economic Transnationalism and its Ambiguities: The Case of Romanian Migration to Italy. International Migration. Volume 50. Issue 6. December, pp.129-149

- $\quad$ BARTRAM, D. (2013). Happiness and ‘economic migration’: A comparison of Eastern European migrants and stayers. Migration Studies. Volume 1, number 2, pp. 156-175.

- BEENSTOCK, M; Chiswick, BR; Repetto, GL. (2001). The effect of linguistic distance and country of origin on immigrant language skills: Application to Israel. INTERNATIONAL MIGRATION. Volume: 39. Issue: 3. Pages: 33-60. DOI: 10.1111/1468-2435.00155

- BLEAHU, A. (2005). Romanian migration to Spain: motivation, networks and strategies. Public Policy Centre (CENPO) (ed.) New patterns of labour migration in Central and Eastern Europe, p. 21-35. Cluj Napoca: CENPO. Google Scholar 
Issue no. 26/2018

- $\quad$ BRUNNER, B.; KUHN, A. (2018) Immigration, Cultural Distance and Natives' Attitudes Towards Immigrants: Evidence from Swiss Voting Results. KYKLOS, Vol. 71 February 2018 - No. 1, 28-58

- $\quad$ COLliER, P.; HOEFflER, A. (2018) Migration, Diasporas and Culture: An Empirical Investigation. KYKLOS, Vol. 71 - February 2018 - No. 1, 86-109

- EASTERLIN, R. (1974). Does economic growth improve the human lot? Some empirical evidence. In P. David \& M. Reder (Eds.), Nations and households in economic growth: essays in honour of Moses Abramovitz, (pp. 98-125). New York and London: Academic Press.

- $\quad$ EUROPEAN SOCIAL SURVEY CUMULATIVE FILE, ESS 1-7 (2016). Data file edition 1.0. NSD - Norwegian Centre for Research Data, Norway - Data Archive and distributor of ESS data for ESS ERIC.

- $\quad$ LIGHT, D. \& YOUNG, C. (2009). European Union enlargement, post-accession migration and imaginative geographies of the 'New Europe': media discourses in Romania and the United Kingdom. Journal of Cultural Geography. Volume 26, 2009 - Issue 3, pp. 281-303

- $\quad$ FRIES-TERSCH, E.; TUGRAN, T.; BRADLEY, H. (2016). 2016 Annual Report on intra-EU Labour Mobility. European Commission. ISBN: 978-92-79-65775-7 doi:10.2767/740419

- HOFSTEDE, G. (2001). Culture’s Consequences: Comparing Values, Behaviours, Institutions and Organizations Across Nations. Second Edition, Sage Publications.

- INGLEHART, R.; WELZEL, C. (2015). The world values survey cultural map of the world. World values surveys project. Retrieved from http://www. worldvaluessurvey. org/WVSContents.Jsp

- IVLEVS, A (2015),Happy Moves? Assessing the Link between Life Satisfaction and Emigration Intentions. KYKLOS, 68, 335-356. doi: 10.1111/kykl.12086.

- MARCU, M. (2015). From the Marginal Immigrant to the Mobile Citizen: Reconstruction of Identity of Romanian Migrants in Spain. Population Space and Place. Volume 21, Issue 6. August. pp. 506-517 
Issue no. 26/2018

- OECD INTERNATIONAL MIGRATION DATABASE. (2017). Downloaded in December 2017 from: http://stats.oecd.org/Index.aspx

- $\quad$ POLGREEN, L.A. \& SIMPSON, N.B. (2011) Happiness and International Migration. Journal of Happiness Studies 12: 819. https://doi.org/10.1007/s10902-010-9229-3

- $\quad$ RODRIGUEZ-POSE, A.; VON BERLEPSCH, V. (2014). Social Capital and Individual Happiness in Europe. Journal of Happiness Studies, 15. Pp. 357-386. DOI 10.1007/s10902013-9426-y

- $\quad$ SANDU, D. (2017). Destination selection among Romanian migrants in time of crisis: An origin integrated approach. Romanian Journal of Population Studies. XI, 2, 2017, pp.145192.

- $\quad$ SANDU, D. (2010). Lumile sociale ale migrației românești în străinătate, Editura Polirom,

- $\quad$ SNEL, E.; BURGERS, J.; ENGBERSEN, G.; ILIES, M.; VAN DER MEIJ, R.; RUSINOVI, K. (2011), Arbeidsmigranten uit Bulgarije, Polen en Roemenië in Rotterdam. Sociale leefsituatie, arbeidspositie en toekomstperspectief.

- $\quad$ SNEL E., FABER M., ENGBERSEN G. (2015). To Stay or Return? Explaining Return Intentions of Central and Eastern European Labour Migrants. Central and Eastern European Migration Review 4(2): 5-24.

- $\quad$ SERBAN, M. \& VOICU, B. (2010). Romanian migrants to Spain: In- or outside the migration networks - A matter of time? Revue d'Etudes Comparatives Est-Ouest, Volume 41, Issue 4, December 2010, Pages 97-124.

- VEENHOVEN, R. (1991). Is happiness relative? Social Indicators Research, Volume 24, pp. 1-34. https://doi.org/10.1007/BF00292648

- VEenhoven, R. (1994). Is Happiness a Trait - Tests of the Theory That a Better Society Does Not Make People Any Happier. Social Indicators Research 32, no. 2.

- VERKUYTEN, M. (2016). The Integration Paradox: Empiric Evidence From the Netherlands. American Behavioral Scientist 2016, Vol. 60(5-6) 583- 596. SAGE Publications. DOI: 10.1177/0002764216632838 
- VOICU, B. \& VASILE, M. (2014). Do “Cultures of Life Satisfaction” Travel? A Cross-European Study of Immigrants, Current Sociology 62(1): 81-99.

- WORLD VALUES SURVEY. Online data analysis. Accessed December 2017. http://www.worldvaluessurvey.org/WVSOnline.jsp

ANNEXES:

APPENDIX 1 Happiness of East European migrants and natives in target countries

\begin{tabular}{|c|c|c|c|c|c|}
\hline \multicolumn{2}{|l|}{$\overline{\text { Country }}$} & \multicolumn{2}{|c|}{ How satisfied with life as a whole } & \multicolumn{2}{|c|}{ How happy are you } \\
\hline & & East Europeans & Natives & East Europeans & Natives \\
\hline \multirow[t]{3}{*}{ Austria } & Mean & 7.08 & 7.52 & 7.37 & 7.48 \\
\hline & $\mathrm{N}$ & 73 & 7021 & 73 & 7029 \\
\hline & Std. Deviation & 2.344 & 2.051 & 2.085 & 1.959 \\
\hline \multirow[t]{3}{*}{ Belgium } & Mean & 6.70 & 7.49 & 7.15 & 7.77 \\
\hline & $\overline{\mathrm{N}}$ & 73 & 9963 & 73 & 9974 \\
\hline & Std. Deviation & 1.949 & 1.749 & 1.838 & 1.490 \\
\hline \multirow[t]{3}{*}{ Switzerland } & Mean & 7.52 & 8.16 & 7.52 & 8.10 \\
\hline & $\overline{\mathrm{N}}$ & 52 & 8079 & 52 & 8074 \\
\hline & Std. Deviation & 1.502 & 1.610 & 1.527 & 1.433 \\
\hline \multirow[t]{3}{*}{ Germany } & Mean & 7.37 & 7.03 & 7.60 & 7.30 \\
\hline & $\overline{\mathrm{N}}$ & 263 & 16954 & 263 & 16925 \\
\hline & Std. Deviation & 2.050 & 2.191 & 1.783 & 1.881 \\
\hline \multirow[t]{3}{*}{ Denmark } & Mean & 8.09 & 8.49 & 8.26 & 8.35 \\
\hline & $\overline{\mathrm{N}}$ & 35 & 9507 & 35 & 9482 \\
\hline & Std. Deviation & 1.380 & 1.487 & 1.221 & 1.404 \\
\hline \multirow[t]{3}{*}{ Spain } & Mean & 6.48 & 7.16 & 7.28 & 7.51 \\
\hline & $\overline{\mathrm{N}}$ & 134 & 12067 & 134 & 12090 \\
\hline & Std. Deviation & 2.452 & 1.957 & 1.994 & 1.743 \\
\hline \multirow[t]{3}{*}{ Finland } & Mean & 7.00 & 7.98 & 7.27 & 8.03 \\
\hline & $\mathrm{N}$ & 11 & 13503 & 11 & 13497 \\
\hline & Std. Deviation & 1.673 & 1.520 & 1.954 & 1.391 \\
\hline \multirow[t]{3}{*}{ France } & Mean & 6.50 & 6.35 & 6.64 & 7.15 \\
\hline & $\overline{\mathrm{N}}$ & 22 & 10141 & 22 & 10141 \\
\hline & Std. Deviation & 2.365 & 2.436 & 1.432 & 1.798 \\
\hline \multirow{3}{*}{$\begin{array}{l}\text { United } \\
\text { Kingdom }\end{array}$} & Mean & 7.25 & 7.14 & 7.51 & 7.47 \\
\hline & $\overline{\mathrm{N}}$ & 93 & 12651 & 95 & 12673 \\
\hline & Std. Deviation & 1.679 & 2.084 & 1.669 & 1.933 \\
\hline \multirow[t]{3}{*}{ Ireland } & Mean & 6.76 & 7.13 & 7.30 & 7.43 \\
\hline & $\mathrm{N}$ & 323 & 12849 & 325 & 12861 \\
\hline & Std. Deviation & 2.132 & 2.139 & 1.848 & 1.940 \\
\hline \multirow[t]{3}{*}{ Italy } & Mean & 5.90 & 6.60 & 6.63 & 6.49 \\
\hline & $\mathrm{N}$ & 20 & 3432 & 19 & 3452 \\
\hline & Std. Deviation & 2.469 & 2.240 & 1.802 & 2.058 \\
\hline
\end{tabular}


On-line Journal Modelling the New Europe

Issue no. 26/2018

\begin{tabular}{llllll} 
Luxembourg & Mean & 6.56 & 8.03 & 7.78 & 7.97 \\
\cline { 2 - 6 } & $\mathrm{N}$ & 9 & 1605 & 9 & 1603 \\
\cline { 2 - 6 } Std. Deviation & 3.539 & 1.909 & 1.856 & 1.788 \\
\hline Netherlands & Mean & 6.95 & 7.66 & 7.30 & 7.78 \\
\cline { 2 - 6 } & $\mathrm{N}$ & 43 & 11420 & 44 & 11416 \\
\cline { 2 - 6 } & Std. Deviation & 1.851 & 1.531 & 1.407 & 1.363 \\
\hline Norway & Mean & 7.89 & 7.88 & 8.10 & 7.98 \\
\cline { 2 - 6 } & $\mathrm{N}$ & 71 & 10122 & 71 & 10116 \\
\hline Sweden & Std. Deviation & 1.573 & 1.652 & 1.406 & 1.498 \\
& Mean & 7.53 & 7.92 & 7.62 & 7.91 \\
\hline Total & $\mathrm{N}$ & 66 & 10238 & 66 & 10221 \\
\cline { 2 - 6 } & Std. Deviation & 1.610 & 1.659 & 1.717 & 1.525 \\
\cline { 2 - 6 } & Mean & 7.06 & 7.47 & 7.45 & 7.66 \\
\cline { 2 - 6 } & Std. Deviation & 1288 & 149552 & 1292 & 149554 \\
\hline
\end{tabular}

Data Source: ESS aggregated file waves1-7

\section{APPENDIX 2}

Descriptives

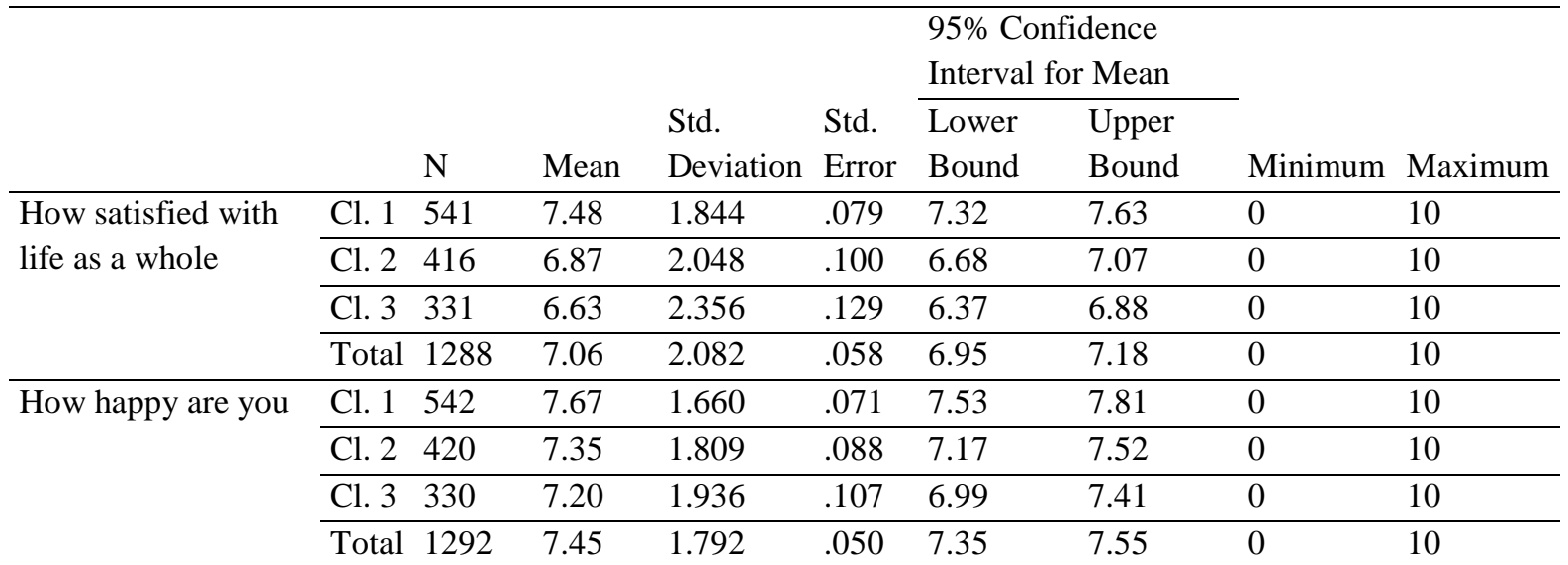

ANOVA

\begin{tabular}{|c|c|c|c|c|c|c|}
\hline & & $\begin{array}{l}\text { Sum of } \\
\text { Squares }\end{array}$ & $\mathrm{df}$ & Mean Square & $\mathrm{F}$ & Sig. \\
\hline \multirow{3}{*}{$\begin{array}{l}\text { How satisfied with life as } \\
\text { a whole }\end{array}$} & Between Groups & 171.105 & 2 & 85.553 & 20.326 & .000 \\
\hline & Within Groups & 5408.546 & 1285 & 4.209 & & \\
\hline & Total & 5579.651 & 1287 & & & \\
\hline \multirow[t]{3}{*}{ How happy are you } & Between Groups & 51.579 & 2 & 25.790 & 8.116 & .000 \\
\hline & Within Groups & 4095.842 & 1289 & 3.178 & & \\
\hline & Total & 4147.421 & 1291 & & & \\
\hline
\end{tabular}


Issue no. 26/2018

Multiple Comparisons

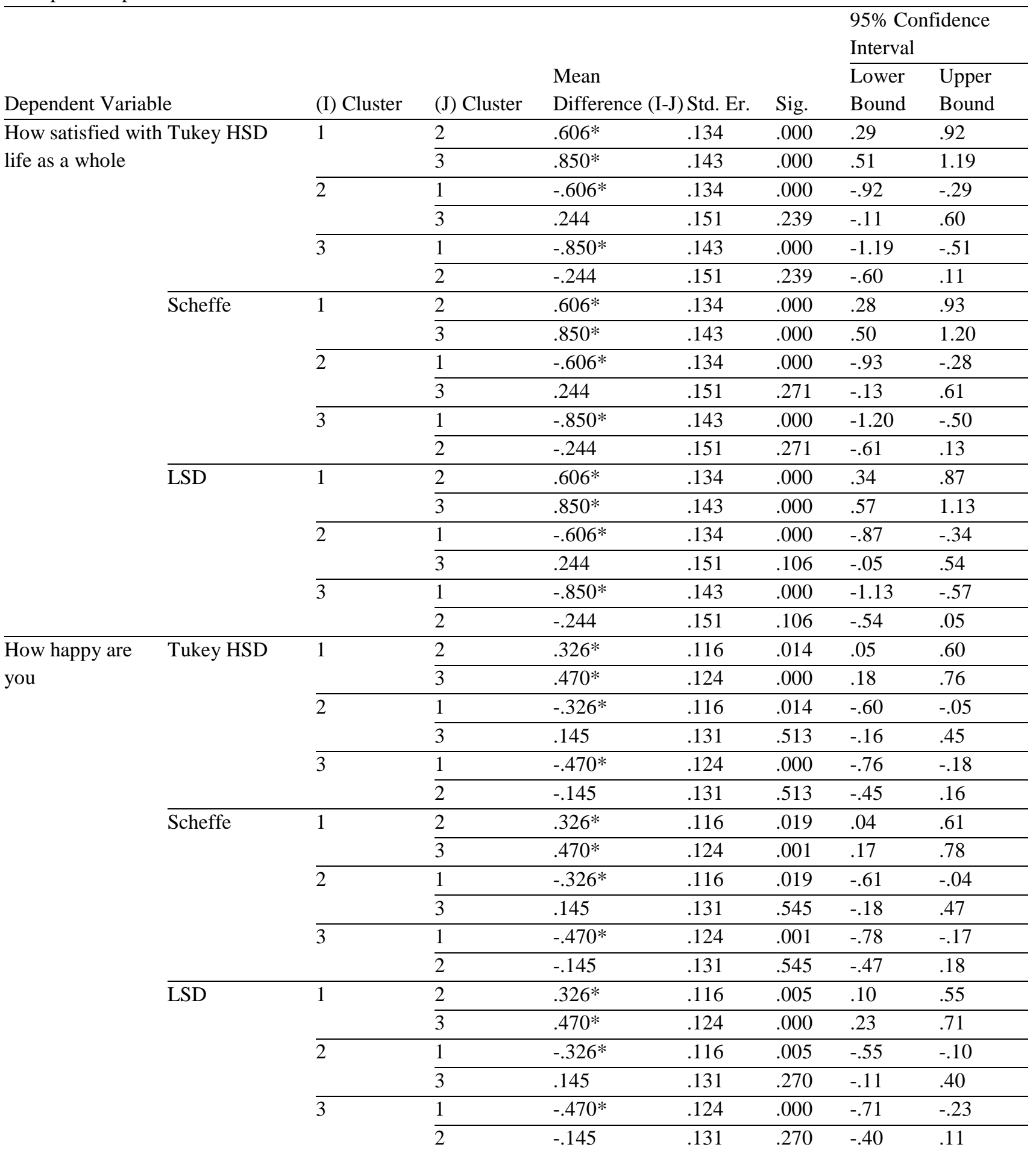

*. The mean difference is significant at the 0.05 level. 
Issue no. 26/2018

APPENDIX 3 Satisfaction with social and economic conditions. Natives*East-European migrants comparison. Country How satisfied How satisfied How satisfied with State of education State of health with present statewith the national the way democracy in country services in country of economy in government works in country nowadays nowadays country

Natives East- Natives East- Natives East- Natives East- Natives East-
Europea Europea European Europeans European

\begin{tabular}{|c|c|c|c|c|c|c|c|c|c|c|c|}
\hline & & & ns & & ns & & $\mathrm{S}$ & & & & $\mathrm{S}$ \\
\hline \multirow[t]{3}{*}{ Austria } & Mean & 5.40 & 5.68 & 4.01 & 4.58 & 5.76 & 6.45 & 5.72 & 6.37 & 6.62 & 7.38 \\
\hline & $\mathrm{N}$ & 8403 & 71 & 8311 & 66 & 8335 & 69 & 8245 & 67 & 8577 & 71 \\
\hline & $\begin{array}{l}\text { Std. } \\
\text { Dev. }\end{array}$ & 2.292 & 2.247 & 2.358 & 2.219 & 2.394 & 2.200 & 2.362 & 2.386 & 2.249 & 1.988 \\
\hline
\end{tabular}

\begin{tabular}{|c|c|c|c|c|c|c|c|c|c|c|}
\hline Belgium Mean & 5.00 & 5.81 & 4.60 & 5.74 & 5.45 & 6.66 & 6.54 & 7.04 & 7.36 & 8.22 \\
\hline$\overline{\mathrm{N}}$ & 12379 & 73 & 12331 & 70 & 12359 & 73 & 12328 & 70 & 12530 & 73 \\
\hline Std. & 2.016 & 1.890 & 2.157 & 2.104 & 2.131 & 1.924 & 1.977 & 2.032 & 1.626 & 1.407 \\
\hline
\end{tabular}

\begin{tabular}{|c|c|c|c|c|c|c|c|c|c|c|c|}
\hline Switzerl & Mean & 6.10 & 6.62 & 5.88 & 6.58 & 6.88 & 7.26 & 6.52 & 6.59 & 6.71 & 6.88 \\
\hline and & $\mathrm{N}$ & 12108 & 52 & 11961 & 48 & 12020 & 50 & 11574 & 46 & 12243 & 50 \\
\hline & Std. & 2.065 & 1.795 & 1.931 & 1.674 & 1.954 & 1.816 & 2.005 & 2.237 & 2.108 & 2.246 \\
\hline
\end{tabular}

\begin{tabular}{|c|c|c|c|c|c|c|c|c|c|c|c|}
\hline German & Mean & 4.58 & 5.42 & 3.96 & 4.72 & 5.33 & 6.15 & 4.62 & 5.15 & 5.00 & 5.91 \\
\hline \multirow[t]{2}{*}{$\mathrm{y}$} & $\overline{\mathrm{N}}$ & 20189 & 261 & 19850 & 248 & 20210 & 257 & 19757 & 246 & 20296 & 258 \\
\hline & $\begin{array}{l}\text { Std. } \\
\text { Dev. }\end{array}$ & 2.454 & 2.531 & 2.252 & 2.499 & 2.439 & 2.319 & 2.237 & 2.470 & 2.410 & 2.465 \\
\hline \multirow{3}{*}{$\begin{array}{l}\text { Denmar } \\
\mathrm{k}\end{array}$} & Mean & 6.40 & 6.58 & 5.34 & 5.93 & 7.25 & 7.27 & 7.48 & 7.53 & 6.38 & 6.57 \\
\hline & $\overline{\mathrm{N}}$ & 10558 & 33 & 10571 & 30 & 10613 & 30 & 10547 & 32 & 10693 & 35 \\
\hline & $\begin{array}{l}\text { Std. } \\
\text { Dev. }\end{array}$ & 2.176 & 1.821 & 2.376 & 1.893 & 1.971 & 1.741 & 1.814 & 1.849 & 2.092 & 2.500 \\
\hline \multirow[t]{3}{*}{ Spain } & Mean & 3.76 & 4.40 & 3.74 & 4.40 & 5.25 & 6.37 & 4.94 & 6.71 & 5.69 & 7.15 \\
\hline & $\mathrm{N}$ & 13285 & 129 & 12965 & 121 & 12978 & 128 & 12752 & 124 & 13353 & 131 \\
\hline & $\begin{array}{l}\text { Std. } \\
\text { Dev. }\end{array}$ & 2.327 & 2.566 & 2.453 & 2.502 & 2.358 & 2.279 & 2.201 & 2.319 & 2.322 & 2.354 \\
\hline
\end{tabular}

\begin{tabular}{|c|c|c|c|c|c|c|c|c|c|c|c|}
\hline \multirow[t]{3}{*}{ Finland } & Mean & 6.06 & 5.89 & 5.70 & 6.20 & 6.48 & 7.30 & 7.88 & 8.10 & 6.82 & 6.60 \\
\hline & $\mathrm{N}$ & 14106 & 9 & 14013 & 10 & 13867 & 10 & 14126 & 10 & 14233 & 10 \\
\hline & $\begin{array}{l}\text { Std. } \\
\text { Dev. }\end{array}$ & 1.905 & 1.691 & 2.042 & 2.201 & 1.920 & 1.418 & 1.391 & 1.287 & 1.917 & 3.026 \\
\hline \multirow[t]{3}{*}{ France } & Mean & 3.32 & 3.73 & 3.72 & 3.95 & 4.63 & 5.45 & 4.97 & 5.33 & 6.06 & 6.52 \\
\hline & $\mathrm{N}$ & 12852 & 22 & 12838 & 22 & 12835 & 22 & 12800 & 21 & 12960 & 21 \\
\hline & $\begin{array}{l}\text { Std. } \\
\text { Dev. }\end{array}$ & 2.029 & 2.272 & 2.229 & 2.400 & 2.387 & 2.444 & 2.127 & 2.176 & 2.183 & 1.940 \\
\hline United & Mean & 4.31 & 6.12 & 4.09 & 5.95 & 5.07 & 6.39 & 5.62 & 5.89 & 5.76 & 6.19 \\
\hline Kingdo & $\mathrm{N}$ & 15252 & 89 & 15323 & 85 & 14855 & 84 & 15035 & 80 & 15564 & 89 \\
\hline $\mathrm{m}$ & $\begin{array}{l}\text { Std. } \\
\text { Dev. }\end{array}$ & 2.282 & 2.142 & 2.358 & 2.176 & 2.389 & 2.094 & 2.111 & 2.176 & 2.345 & 2.467 \\
\hline
\end{tabular}


Issue no. 26/2018

\begin{tabular}{|c|c|c|c|c|c|c|c|c|c|c|c|}
\hline Ireland & Mean & 4.13 & 4.69 & 3.96 & 4.67 & 5.18 & 6.41 & 6.36 & 6.83 & 4.09 & 5.66 \\
\hline & $\mathrm{N}$ & 15255 & 312 & 13140 & 267 & 14655 & 277 & 14940 & 258 & 15255 & 287 \\
\hline & $\begin{array}{l}\text { Std. } \\
\text { Dev. }\end{array}$ & 2.656 & 2.358 & 2.472 & 2.280 & 2.417 & 2.072 & 2.219 & 2.022 & 2.534 & 2.574 \\
\hline Italy & Mean & 3.60 & 3.47 & 3.58 & 3.17 & 4.65 & 4.82 & 4.90 & 5.65 & 4.73 & 6.40 \\
\hline & $\overline{\mathrm{N}}$ & 3577 & 19 & 3492 & 18 & 3541 & 17 & 3519 & 20 & 3648 & 20 \\
\hline & $\begin{array}{l}\text { Std. } \\
\text { Dev. }\end{array}$ & 2.141 & 1.744 & 2.393 & 2.229 & 2.274 & 1.912 & 2.107 & 1.954 & 2.286 & 2.088 \\
\hline Luxemb & Mean & 6.55 & 7.38 & 6.27 & 5.88 & 6.73 & 6.14 & 5.37 & 5.67 & 7.07 & 6.29 \\
\hline ourg & $\mathrm{N}$ & 2946 & 8 & 2852 & 8 & 2894 & 7 & 2808 & 9 & 3116 & 7 \\
\hline & $\begin{array}{l}\text { Std. } \\
\text { Dev. }\end{array}$ & 2.056 & 2.875 & 2.077 & 3.441 & 2.192 & 3.532 & 2.496 & 2.449 & 2.304 & 2.215 \\
\hline Netherla & a Mean & 5.44 & 5.74 & 4.96 & 5.14 & 6.00 & 6.26 & 5.90 & 6.25 & 5.98 & 6.49 \\
\hline nds & $\bar{N}$ & 13359 & 42 & 13265 & 36 & 13191 & 39 & 12674 & 36 & 13406 & 39 \\
\hline & $\begin{array}{l}\text { Std. } \\
\text { Dev. }\end{array}$ & 1.843 & 1.951 & 1.973 & 2.180 & 1.826 & 2.173 & 1.700 & 1.746 & 1.923 & 1.684 \\
\hline Norway & Mean & 6.97 & 7.82 & 5.02 & 6.38 & 6.69 & 7.59 & 6.51 & 6.77 & 6.06 & 6.69 \\
\hline & $\mathrm{N}$ & 11621 & 71 & 11573 & 66 & 11566 & 68 & 11568 & 64 & 11673 & 70 \\
\hline & $\begin{array}{l}\text { Std. } \\
\text { Dev. }\end{array}$ & 2.129 & 1.783 & 2.091 & 1.936 & 1.964 & 1.721 & 1.813 & 2.195 & 2.072 & 2.313 \\
\hline Sweden & Mean & 5.65 & 5.81 & 5.25 & 5.68 & 6.42 & 7.44 & 5.45 & 5.86 & 5.75 & 5.70 \\
\hline & $\mathrm{N}$ & 10956 & 67 & 10738 & 66 & 11048 & 66 & 10967 & 64 & 11252 & 66 \\
\hline & $\begin{array}{l}\text { Std. } \\
\text { Dev. }\end{array}$ & 2.082 & 2.076 & 2.197 & 2.106 & 2.105 & 1.866 & 2.015 & 2.260 & 2.171 & 2.060 \\
\hline Total & Mean & 5.07 & 5.42 & 4.60 & 5.07 & 5.80 & 6.51 & 5.95 & 6.26 & 5.93 & 6.36 \\
\hline & $\mathrm{N}$ & 176846 & 1258 & 173223 & 1161 & 174967 & 1197 & 173640 & 1147 & 178799 & 1227 \\
\hline & $\begin{array}{l}\text { Std. } \\
\text { Dev. }\end{array}$ & 2.439 & 2.443 & 2.357 & 2.383 & 2.334 & 2.167 & 2.246 & 2.316 & 2.347 & 2.435 \\
\hline
\end{tabular}

